\title{
Shadows bordering the lung on radiographs of normal and obese persons
}

\author{
M. C. GLUCK ${ }^{1}, H$. L. TWIGG, M. F. B A LL, and P. G. RHODES \\ Department of Medicine and Radiology, The Georgetown University School of Medicine, Washington, D.C \\ and the New York Medical College
}

The thickness of the shadows that accompany ribs or border the lungs on the chest posteroanterior radiographs of 22 obese patients and 22 normal-weight subjects was measured, when present, at several rib levels. A similar measurement was made of accompanying rib shadows on chest postero-anterior radiographs of eight obese patients after weight reduction. Statistical analysis showed that there were significantly thicker soft tissue shadows adjacent to the ribs of obese subjects compared to normal-weight persons and of obese subjects before as compared to after weight reduction. Such shadows are more frequent and are seen at more rib levels of the obese.

In addition, the following pertinent features are discussed: the mechanism by which soft tissue projects a radiographic shadow, the factors affecting its appearance, and the significance of such shadows as a variant of the normal chest radiograph and not as a manifestation of pathology.

The chest radiograph has variants which are difficult to interpret and to differentiate from the $a b$ normal. One of these variants is a shadow bordering the lung near the apex, sometimes seen on the postero-anterior chest radiograph (Fig. 1). Bordering shadows such as these have been ascribed by Fleischner (1927) to abnormal conditions such as pleural thickening, to pleural capping by Medlar (1947) and Pagel, Simmonds, MacDonald, and Nassau (1964) or simply to soft tissue, primarily fat, underlying or accompanying ribs by several reporters (Herrnheiser, 1933; Knutsson, 1932 ; Kubat and Neugebauer, 1936 ; Zawadowski, 1936).

The prime purpose of this paper is to evaluate the hypothesis that, in the absence of overt pathology, a shadow bordering the lung near the apex or accompanying ribs is composed mostly of fatty tissue between the rib and the parietal pleura. This hypothesis is tested by measuring and then comparing the thickness of such shadows on the postero-anterior chest radiograph of (1) obese patients and normal-weight subjects and (2) obese patients before and after weight reduction.

In addition, the mechanism by which such shadows appear is reviewed. The factors affecting

1Present address: Pulmonary Division, Metropolitan Hospital, 1901 First Avenue, New York, N.Y. 10029 the presence and the thickness of these shadow and their significance are discussed.

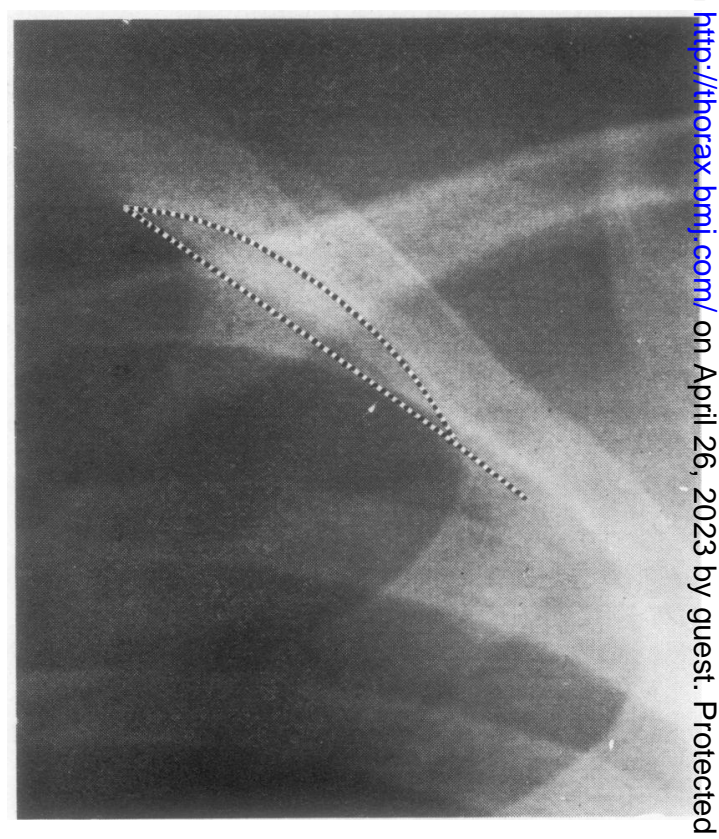

FIG. 1. Close-up of left upper lung field showing a shado bordering the lung. 


\section{METHODS}

Postero-anterior chest radiographs of 22 patients, 10 males and 12 females, were taken immediately after admission to the Clinical Research Facility of the Georgetown University Hospital as part of a research programme evaluating obesity. Chest radiographs were also available for eight of these patients after they had lost a significant amount of weight (49-152 lb). The following information was recorded for each patient: age, sex, height, weight, and difference from ideal weight as determined by Solomon (1969). For the eight patients who had chest radiographs after weight reduction the following was recorded: amount of weight loss, the time interval between radiographs and the thickness of the soft tissue shadows at the several lateral rib levels. Comparisons were made with the measurements before weight reduction.

A control group of 10 males and 12 females without known physical ailment or chest pathology was selected from the Employee Health Service of Georgetown University Hospital. The ages of the control subjects were comparable with those of the obese patients.

Measurements of the thickness of the soft tissue shadows from the inner rib margin to the pleural surface were recorded in the following manner: measurements were made at the level of the second to sixth ribs laterally by three independent observers using a transparent ruler, and the thickness of the soft tissue shadow was recorded to the nearest half millimetre (Figure 2). A final measurement was the mean of the three observations.

The thickness of the soft tissue shadows accompanying the ribs on both sides of the chest radiograph at the level of the second and third ribs was compared between (1) the obese males and normal males, (2) the obese females and normal females, (3) the entire obese group of patients and the normal subject group, and (4) eight obese patients before and after weight reduction.

\section{RESULTS}

Table I lists the mean and standard error of the mean of the obese and normal-weight subjects with their age, height, weight, difference from ideal weight, and the thickness of the accompanying shadows measured in millimetres on each side of the chest radiograph at the level of the second to sixth ribs. The mean weight of the obese males was $336.8 \mathrm{lb}$ and of the obese females $259.3 \mathrm{lb}$, which differed from the ideal weight by 175.8 and $131.0 \mathrm{lb}$ respectively. The control or normal-weight subjects were similar to the obese group in age and height. The mean

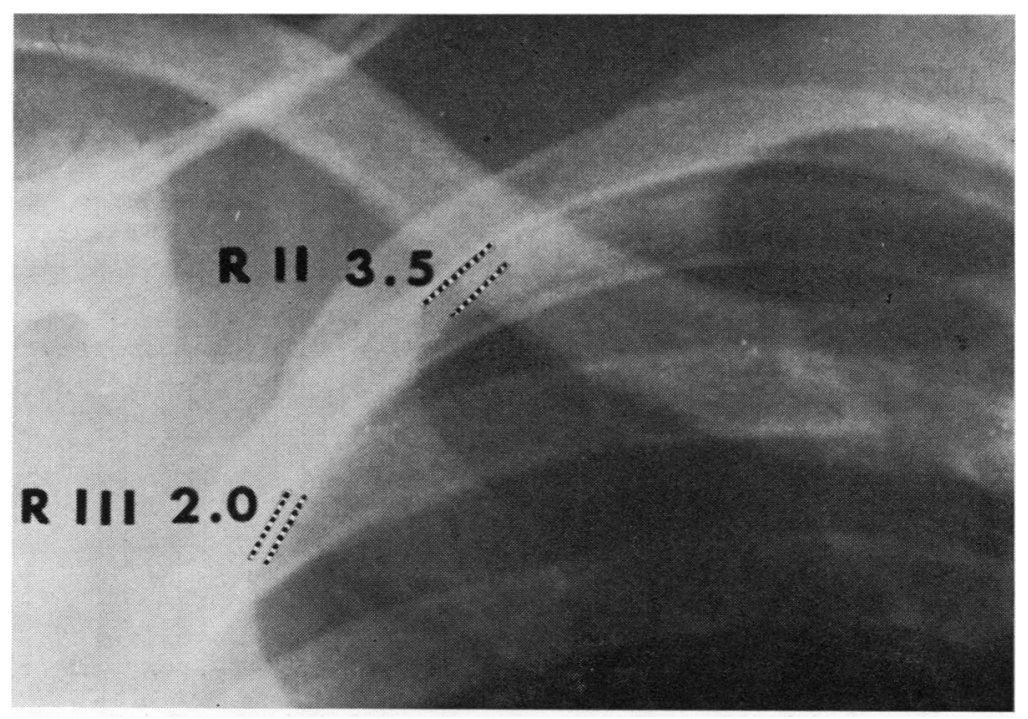

FIG. 2. Close-up of right upper lung field of chest radiograph of patient J.J. weighing $380 \mathrm{lb}$. The thickness of the soft tissue shadow at the level of the second rib is $3.5 \mathrm{~mm}$ and at the level of the third rib is $2.0 \mathrm{~mm}$. 
T A B LE I

COMPARISON OF SOFT TISSUE SHADOWS OF NORMAL AND OBESE INDIVIDUALS

\begin{tabular}{|c|c|c|c|c|c|c|c|c|c|}
\hline & \multirow{3}{*}{$\begin{array}{l}\text { Age } \\
(y r)\end{array}$} & \multirow{3}{*}{$\begin{array}{l}\text { Height } \\
\text { (in) }\end{array}$} & \multirow{3}{*}{$\begin{array}{l}\text { Weight } \\
\text { (lb) }\end{array}$} & \multirow{3}{*}{$\begin{array}{l}\text { Difference } \\
\text { from Ideal } \\
\text { Weight } \\
\text { (lb) }\end{array}$} & \multicolumn{5}{|c|}{ Thickness of Accompanying Shadow (mm) } \\
\hline & & & & & \multicolumn{2}{|c|}{ 2nd Rib } & 3rd Rib & \multicolumn{2}{|c|}{ 4th Rib } \\
\hline & & & & & $\mathbf{R}$ & $\mathbf{L}$ & $\mathbf{R}$ & $\mathbf{R}$ & $\mathbf{L}$ \\
\hline $\begin{array}{l}\text { Males } \\
\text { Obese } \\
\text { Normal }\end{array}$ & $\begin{array}{l}25 \cdot 0+3 \cdot 7^{1} \\
28 \cdot 8+3 \cdot 4^{1}\end{array}$ & $\begin{array}{l}71 \cdot 0+0.7 \\
68.9+0.8\end{array}$ & $\begin{array}{l}336 \cdot 8+13 \cdot 8 \\
165 \cdot 3+5 \cdot 2\end{array}$ & $\begin{array}{r}175 \cdot 8+12 \cdot 6 \\
22 \cdot 2+5 \cdot 2\end{array}$ & $\begin{array}{l}2 \cdot 7+0 \cdot 6 \\
1 \cdot 8+0 \cdot 3\end{array}$ & $\begin{array}{l}2 \cdot 0+0 \cdot 6 \\
1 \cdot 4+0 \cdot 4\end{array}$ & $\begin{array}{ll}1.9+0.5 & 1.7+0.5 \\
0.9+0.4 & 0.3+0.9\end{array}$ & $\begin{array}{l}0.9+0.5 \\
\text { Absent }\end{array}$ & $\begin{array}{l}0.8+0.4 \\
\text { Absent }\end{array}$ \\
\hline $\begin{array}{l}\text { Females } \\
\text { Obese } \\
\text { Normal }\end{array}$ & $\begin{array}{l}24 \cdot 4+2 \cdot 8^{1} \\
23 \cdot 4+2 \cdot 0^{1}\end{array}$ & $\begin{array}{l}64 \cdot 3+1 \cdot 1 \\
63 \cdot 4+0 \cdot 6\end{array}$ & $\begin{array}{l}259 \cdot 3+14 \cdot 2 \\
123 \cdot 7+4 \cdot 0\end{array}$ & $\begin{array}{r}131 \cdot 0+14 \cdot 8 \\
4 \cdot 8+4 \cdot 8\end{array}$ & $\begin{array}{l}2 \cdot 2+0 \cdot 4 \\
0 \cdot 7+0 \cdot 2\end{array}$ & $\begin{array}{l}2 \cdot 5+0 \cdot 5 \\
0 \cdot 6+0 \cdot 2\end{array}$ & $\begin{array}{l}1 \cdot 0+0.4 \quad 1.6+0.6 \\
0.04+<0.1 \text { Absent }\end{array}$ & $\begin{array}{c}1 \cdot 8+0.3 \\
\text { Absent }\end{array}$ & $\begin{array}{r}0.2+0.2 \\
\text { Absent }\end{array}$ \\
\hline
\end{tabular}

Mean and standard error of the mean

weight of the control males was $22 \cdot 2 \mathrm{lb}$ greater than the ideal weight for their age and height according to the weight prediction chart of Solomon (1969), while the mean weight for the females was $4.8 \mathrm{lb}$ greater than their ideal weight. Although some control subjects were somewhat overweight (one subject, W. W., was $64 \mathrm{lb}$ greater than the ideal weight), none was as far from the ideal weight as the obese individuals. The minimal difference from the ideal weight for the obese group was $80 \mathrm{lb}$ with a maximum of $273 \mathrm{lb}$.

The thickness of the accompanying soft tissue shadows is usually more at the second rib level and is progressively less thick at lower rib levels. The average thickness of the soft tissue shadows for the entire obese group at the level of the second rib was $2.35 \mathrm{~mm}$, while at the third rib it was $1.55 \mathrm{~mm}$ and at the fourth rib $0.93 \mathrm{mmN}$ As with the obese subjects, when accompanying soft tissue shadows were observed on the chest radiograph of the normal or control subjects, iR was most often thicker at the higher rib levels Such shadows were not observed below the third? rib on radiographs of normal-weight subjects.

A statistical comparison of the thickness of the shadows for all obese patients with all controb subjects at the second and third rib levels on both sides showed that there was a significant differ ence $(P<0.01)$. When the sexes were compared separately, the females had a difference of greatex significance $(\mathrm{P}<0.001)$. The histograms in Fig. graphically demonstrate the difference in measured thickness of the accompanying soft tissue shadows

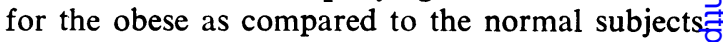
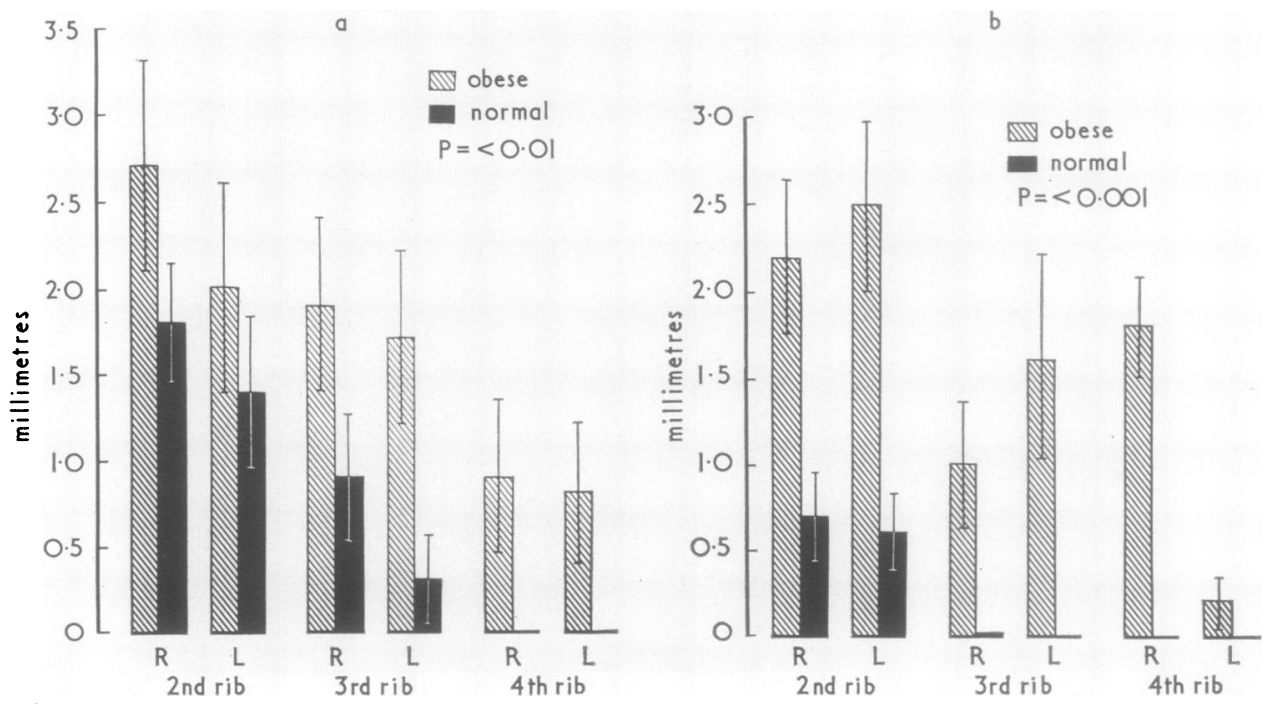

FIG. 3. The thickness of accompanying soft tissue shadows of (a) obese and normal males and (b) obese and normati females. The bar height represents the mean, and the vertical line illustrates the standard error of the mean. 


\section{T A B LE I I}

COMPARISON OF SOFT TISSUE SHADOWS OF EIGHT OBESE SUBJECTS BEFORE AND AFTER WEIGHT REDUC-

\begin{tabular}{|c|c|c|c|c|}
\hline & $\begin{array}{l}\text { Weight } \\
\text { (lb) }\end{array}$ & $\begin{array}{c}\text { Difference } \\
\text { from Ideal } \\
\text { Weight } \\
\text { (lb) }\end{array}$ & $\begin{array}{l}\text { Weight Loss } \\
\text { (lb) }\end{array}$ & $\begin{array}{c}\text { Thickness } \\
(\mathrm{mm})\end{array}$ \\
\hline $\begin{array}{l}\text { Obese } \\
\text { Thinned }\end{array}$ & $\begin{array}{l}281 \cdot 0+16 \cdot 0^{1} \\
179 \cdot 4+8 \cdot 9^{1}\end{array}$ & $\begin{array}{r}145 \cdot 9+10 \cdot 0 \\
43 \cdot 5+9 \cdot 5\end{array}$ & $101 \cdot \overline{6+} 11 \cdot 5$ & $\begin{array}{l}2 \cdot 9+0 \cdot 2 \\
1 \cdot 2+0 \cdot 2\end{array}$ \\
\hline
\end{tabular}

${ }^{1}$ Mean and standard error of the mean

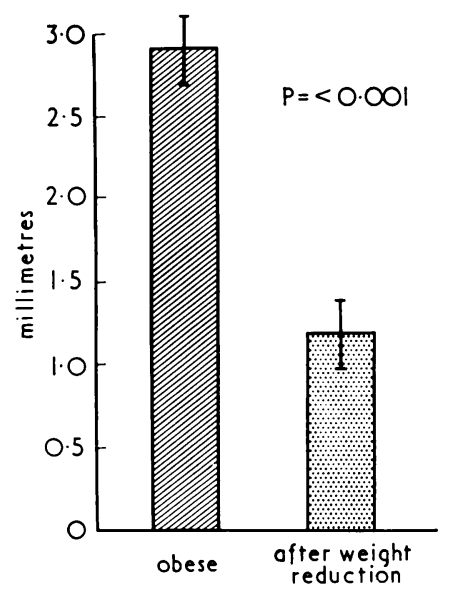

FIG. 4. The thickness of accompanying soft tissue shadows of eight thinned obese subjects. The bar height represents the mean, and the vertical line illustrates the standard error of the mean.

Table II lists the eight patients for whom the change in thickness of the accompanying soft tissue shadows was charted after weight reduction. The weight after dieting differed from the predicted weight by 6 to $90 \mathrm{lb}$, and the average weight loss over a 4- to 12-month period was over $100 \mathrm{lb}$ for the group. The decrease in thickness of the accompanying soft tissue shadows for this group before and after weight reduction was statistically significant $(\mathrm{P}<0.001)$. Figure 4 graphically demonstrates this difference and Fig. 7 illustrates the difference radiographically.

\section{DISCUSSION}

Shadows bordering the lung on a chest radiograph are not newly considered. Albers-Schönberg (1913) described the shadow as a stripe under the angle of the second rib on the postero-anterior radiograph, and Fleischner (1927) described the shadow as being due to soft tissue bordering the lung on the oblique radiograph.

There had been speculation as to the composition of the tissue. It had been considered a result of pleuritis by Fleischner (1927), as the upper lung border by Assmann (1929), and as normal soft tissue structures situated on the inner surface of the ribs by Herrnheiser (1933). However, subsequent anatomic dissection by Knutsson (1932) showed the shadows to be composed of a layer of muscle covering the inner surface of the ribs and subsequently by Kubat and Neugebauer (1936) to be composed mostly of fat. Finally, from anatomical studies, thoracoscopic investigation, and model radiography, as performed by Zawadowski (1936), it was demonstrated that these shadows were due to adipose tissue, fascia, and muscle tissue lying between the rib and the parietal pleura. Not all have shown that such shadows are caused by benign or normal tissue. A bordering lung shadow has been called an 'apical cap' by Medlar (1947), and from microscopic necropsy studies without radiographic correlation he considered it to be due to pleural adhesions. Others have considered apical caps a result of tuberculous infection, dust deposition or post-pneumonic scars.

Our study does not include anatomical correlation. However, the lack of radiographic apical calcification and fibrosis suggests an absence of lung pathology. The shadows evaluated on the films of this study have smooth laterally tapering margins compatible with benign soft tissue.

The way in which such soft tissue accompanying ribs may cast a radiographic shadow may be simply understood by noting how soft tissue accompanying the clavicle projects a shadow. Figure 5 illustrates that as soft tissue folds over the clavicle it causes a radiographic shadow only when the soft tissue surface is met tangentially by roentgen rays (1A, $1 \mathrm{~B}$ and $2 \mathrm{~A}, 2 \mathrm{~B})$. On the other hand, if roentgen rays do not meet the soft tissue surface tangentially (3A, 3B) no soft tissue shadow is projected on to the radiograph.

Soft tissue shadows of ribs are projected in a similar fashion. Figure 6 illustrates how soft tissue bulging inward from the second posterior rib projects a radiographic shadow. As illustrated, the surface of the soft tissue bulge of that rib is the only one that is met tangentially by roentgen rays. Therefore, the second rib is the only rib in this example that has an accompanying soft tissue shadow.

The composition of the soft tissue between the rib surface and the pleura causing this radio- 
A
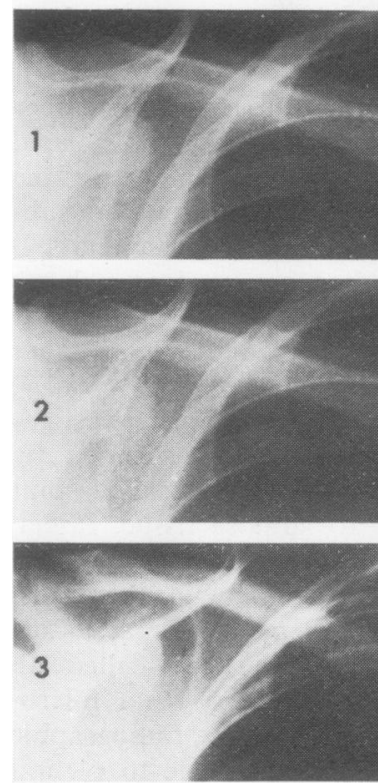

B
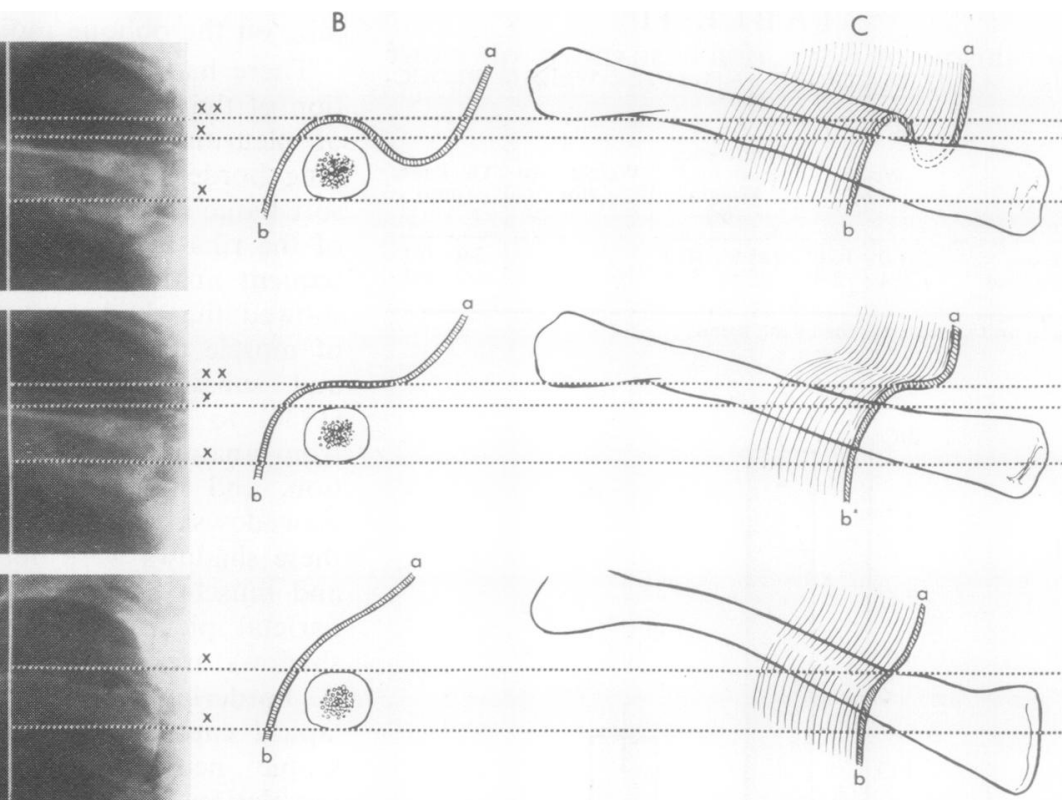

FIG. 5. Radiographs of the right clavicle in column $A$ represent projections of anatomical relationships of respective illustrations from columns $B$ and $C$. Column $B$ shows the sagittal sections throughout plane $a-b$ as illustrated by th skin cut-away in column $C$. The dotted line $(x)$ represents roentgen rays that project the clavicle borders on to the radio 2 graph. The dotted line $(x x)$ in views $1 B$ and $2 B$ represents the roentgen ray that meets the skin surface tangentially $\vec{B}$ The tangential ray causes a soft tissue border, as indicated by the dotted lines in the respective radiographs. In row 3 , nঙㅗ roentgen rays meet the skin surface tangentially and, therefore, no soft tissue shadow is projected on to the respective radiograph $(3 A)$.

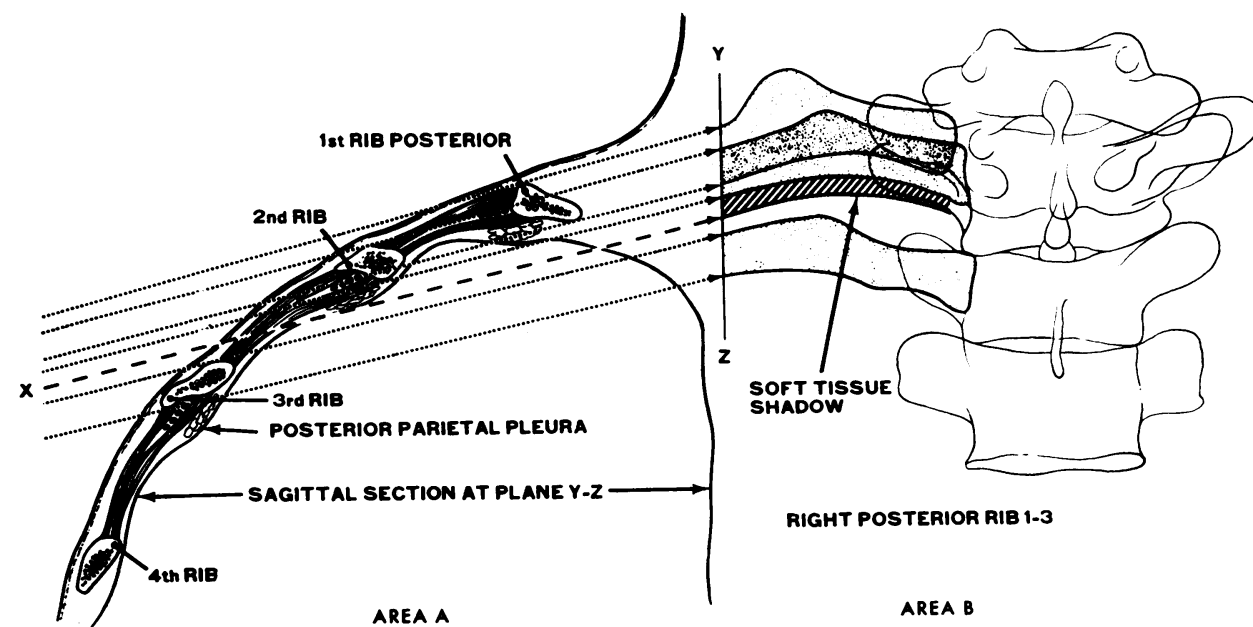

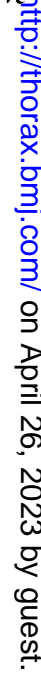

FIG. 6. Area $A$ is the sagittal section of the right posterior first to fourth ribs at plane $Y$-Z. The ribs are numbered and ure joined by intercostal muscles. Between these structures and the parietal pleura is adipose tissue drawn as irregula circles. The bulging toward the pleural cavity at the rib levels is accentuated by adipose tissue. The dotted lines ar: roentgen rays that meet the rib borders tangentially and cause their projection, as pictured in area $B$. Roentgen ray $\mathcal{S}^{\circ}$ that meet other surfaces tangentially also project them. Thus, the dashed line $(X)$ meets the parietal pleura tangentially and projects a line that borders the soft tissue shadow accompanying the second rib. 

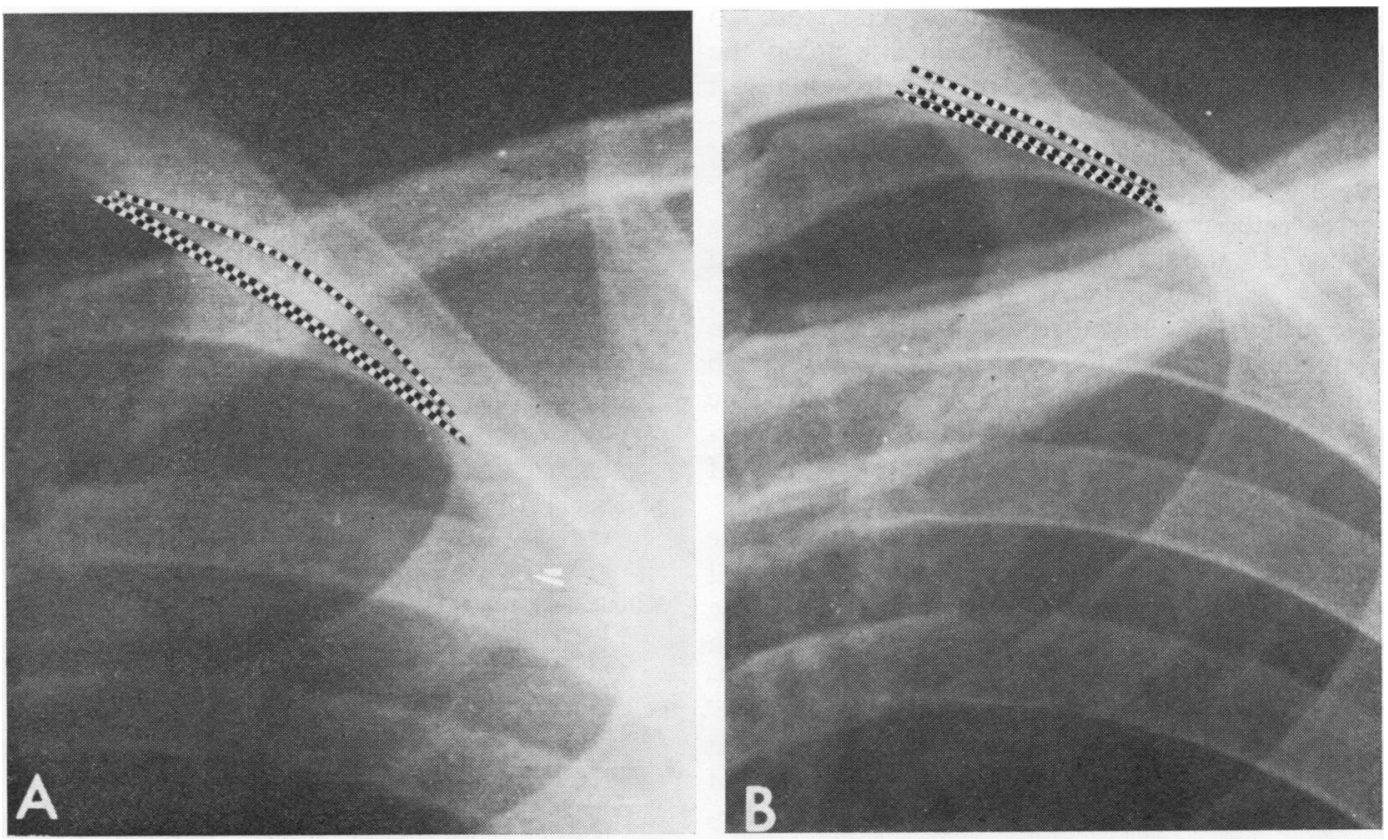

FIG. 7. Close-ups of the left upper lung field of the chest radiograph of an obese patient $(A)$ when weighing 280 lb and (B) after weight reduction to $180 \mathrm{lb}$. The thickness of the soft tissue shadow at the level of the second rib measured $5 \cdot 5 \mathrm{~mm}$ when the patient was obese and $2.5 \mathrm{~mm}$ after weight reduction.

density on the radiograph, as mentioned previously, has been shown to be due to connective tissue, muscle, and mostly fat by several investigators (Herrnheiser, 1933 ; Knutsson, 1932 ; Kubat and Neugebauer, 1936; Zawadowski, 1936). The findings of the present investigation support the view that fat is the significant tissue of these shadows. This study shows a significantly greater thickness of the accompanying soft tissue shadows on the postero-anterior chest radiograph of obese patients as compared to that of normal-weight subjects (Table I) and a significant decrease in the radiographic thickness of such shadows after weight reduction in eight obese patients (Table II and Figs 4 and 7).

There are certain obvious limitations or potential errors in the determination of the thickness of the accompanying soft tissue shadows. The thickness may vary with the angle of the roentgen rays and the position of the thorax during radiography. Therefore, there may be a difference in the measured thickness of this density on different radiographs of the same individual with unintentional changes in posture while the radiographs are being taken. The decreased abdominal girth after weight reduction may also allow the indi- vidual to assume a different posture against the roentgen plate and alter the angle of projection. Differences in intrathoracic volume as the subject holds his breath at inspiration and the different levels of beam centring are other variables which may influence the thickness of soft tissue shadows. The radiographs of this study were evaluated retrospectively, and extrinsic variables which could affect the radiographic thickness of the accompanying soft tissues of the ribs could not be controlled.

The incidence of bordering soft tissue shadows on the normal postero-anterior radiograph is not known. In this study, using 22 normal chest radiographs as controls, soft tissue shadows are visible in $3 \%$ at the second rib level and in $1 \%$ at the third rib level. The number of normal subjects in this study is too small to project a population incidence. Felson (1960) states that $7.3 \%$ of a large series of 14 by 17 inch chest radiographs of apparently normal individuals showed some degree of apical 'cap'. Apical capping has not been clearly defined. It may be due to fibrosis at the lung apex, as described by Pagel et al. (1964); however, it may be mistaken for an extrapulmonary density such as the bordering shadows 
of chest wall tissue here described. Therefore, to use the $7 \cdot 3 \%$ incidence of apical capping in the normal adult for the incidence of bordering soft tissue shadows in normal subjects would be presumptuous. On the other hand, the incidence of bordering soft tissue shadows on the posteroanterior radiograph of the obese patients in this study is $73 \%$ at the second rib, $50 \%$ at the third rib, $18 \%$ at the fourth rib, $17 \%$ at the fifth rib, and less than $1 \%$ at the sixth rib level. Rarely, in the normal and obese, are accompanying rib shadows seen at the level of the first rib. The lower border of this rib is most often superimposed by bone and soft tissue densities of lower ribs.

In conclusion, the accompanying soft tissue shadows of the ribs are projections of normal tissue. When seen at the apical border of the chest radiograph they may be confused with pathology. However, the presence of a welldefined tapering margin, the lack of 'fibrotic' streaking and calcification, and their presence at several rib levels strongly suggest shadows of normal soft tissue. Such shadows are more frequent, more thick, and at more rib levels on radiographs of the obese. This suggests that they consist mostly of adipose tissue.

This study was supported in part by grants from the Departments of HEW and NIAMD.

\section{REFERENCES}

Albers-Schönberg, H. (1913). Die Röntgentechnik, 4th ed. p. 534. Gräfe and Sillem, Hamburg.

Assmann, H. (1929). Die Klinische Röntgendiagnostik der Inneren Erkrankungen, 4th ed., p. 221. Vogel, Leipziges

Felson, B. (1960). Fundamentals of Chest Roentgenology $\overrightarrow{0}$ p. 267. Saunders, Philadelphia and London.

Fleischner, F. (1927). Die lamelläre Pleuritis. Fortschr. Röntgenstr., 36, 120.

Herrnheiser, G. (1933). In Vereinigung Deutscher Rönt genologen und Radiologen in der Tschechoslowakischen Republik. X Tagung vom 28 bis 30 Okotober 1932 irị Prag. Fortschr. Röntgenstr., 48, 123.

Knutsson, F. (1932). Zur Kenntnis der normalen Rönt genologie der Pleura Parietalis. Acta radiol. (Stockh.) 13음 638.

Kubat, A., and Neugebauer, W. (1936). Das Substrat de Begleitstreifen in der Seitenkrümmung der mittleren unc్ unteren Rippen (lamelläre Pleuritis). Fortschr. Röngenstr., $53,53$.

Medlar, E. M. (1947). Apical scars. Amer. Rev. Tuberc., 55 511.

Pagel, W., Simmonds, F. A. H., MacDonald, N., ands Nassau, E. (1964). Pulmonary Tuberculosis, 4th ed.? p. 214. Oxford University Press, London.

Solomon, N. (1969). The study and treatment of the obeseD patient. Hosp. Pract., 4, 90.

Zawadowski, W. (1936). Über die Schattenbildungen an de옴 Lungen-Weichteilgrenze. Fortschr. Röngenstr., 53, 306. 